\title{
Molecular Epidemiology of Staphylococcus spp. Contamination in the Ward Environment: Study on mecA and fem A Genes in Methicillin-Resistant Strains
}

\author{
Atsushi ASHIMOTO and Takeshi HAMADA \\ Department of Oral and Maxillofacial Surgery, Faculty of Medicine, Tottori University \\ Akiko ADACHI, Takahiko TANIGAWA and Yoshinori TANAKA \\ Department of Bacteriology, Faculty of Medicine, Tottori University \\ (Received: June 22, 1994) \\ (Accepted: September 13, 1994)
}

Key words: methicillin-resistant Staphylococcus aureus (MRSA), mecA gene, femA gene

\begin{abstract}
Staphylococcus spp. were isolated from the ward environment and antibiotic susceptibility tests were performed. Twenty-nine strains out of 274 isolates were $S$. aureus, and $41.4 \%$ of the $S$. aureus strains were methicillin resistant (MRSA). All 12 strains of MRSA were also resistant to oxacillin, ceftizoxime, ampicillin and clindamycin. Among the coagulase-negative staphyloccocci (CNS), methicillin-resistant (MR) strains of S. epidermidis, S. capitis, S. warneri, S. haemolyticus, S. hominis, S. auricularis, S. saprophyticus and S. cohnii were isolated. Eight of the $10 \mathrm{~S}$. haemolyticus strains were methicillin resistant. The fem A gene was detected in S. aureus (MSSA and MRSA), but not in CNS by polymerase chain reaction (PCR) analysis and Southern blot analysis. The mec A gene was found in all the MRSA and MR-S. epidermidis strains tested, and one of the two MR-S. hominis strains, but not in MSSA, MS-S. epidermidis, MS-S. hominis, or MS-S. haemolyticus. DNA from one strain of MR-S. hominis and 2 strains of MR-S. haemolyticus was not amplified by PCR using the mec A gene primer, or hybridized by Southern blotting. The ambiguity that mecA was detected in some MR-CNS strains, but not in others is discussed.
\end{abstract}

\section{Introduction}

Infection with Staphylococcus aureus is one of the most important nosocomial infections in the hospital, because a high frequency of methicillin resistance is found in $S$. aureus. Recently, genetic studies on the methicillin resistance have been encouraged ${ }^{1,2,3,4}$. The resistance is evoked by the penicillin-binding protein-2'(PBP-2') which is encoded in the chromosomal mec A gene. It was also reported that the mec A gene present in coagulase-negative staphylococci (CNS) is horizontally transferred to $S$. aureus ${ }^{5}$. In this experiment, we isolated Staphylococcus strains from the general ward of Tottori University Hospital and tested their drug susceptibility. Then, the mec A gene and fem A gene were investigated in Staphylococcus by the polymerase chain reaction (PCR) and Southern blot analysis.

\section{Materials and Methods}

\section{Bacteria}

Correspondence to: Atsushi ASHIMOTO, Department of Oral and Maxillofacial Surgery, Faculty of Medicine, Tottori University. 86 Nishimachi, Yomago, 683, Japan 
The Staphylococcus strains were collected from the University Hospital ward in December 1992 and April 1993. Sterile swabs were rubbed on 5 separate sites of the floor of the ward and on the surface of fixtures, and each swab was streaked directly on a nutrient agar plate. The plates were incubated for 24 to $48 \mathrm{hr}$ at $37^{\circ} \mathrm{C}$. Bacteria from each colony were transferred to a glass slide for gram staining, and gram-positive cocci were further selected by oxidation-fermentation and catalase tests. Bacteria from 4 to 5 colonies were separately picked from each plate. Species of Staphylococcus were identified with the N-ID test - SP-18 (Nissui Seiyaku Co. Ltd., Tokyo).

2. Antibiotic susceptibility

Antibiotic susceptibility testing was performed by the disk method described elsewhere $(\mathrm{NCCLS})^{8}$, using methicillin (DMPPC), oxacillin (MPIPC), ceftizoxime (CZX), ampicillin (ABPC), cefazolin (CEZ), cefmetazole (CMZ), imipenem (IPM), gentamicin (GM), clindamycin (CLDM), lomefloxacin (LFLX), minocycline (MINO), sulfamethoxazole-trimethoprim (ST) and vancomycin (VCM) (all from Showa Yakuhin Kako Co. Ltd., Tokyo). According to the manufacturer's instructions, methicillin-resistant S. aureus (MRSA) was identified by zone diameters of $\leqq 20 \mathrm{~mm}$ for $30 \mu \mathrm{g}$ of DMPPC, $\leqq 20 \mathrm{~mm}$ for $30 \mu \mathrm{g}$ of MPIPC, and $\leqq 16 \mathrm{~mm}$ for $30 \mu \mathrm{g}$ of CZX, after incubation on Mueller-Hinton medium for $16-18 \mathrm{hr}$ at $35^{\circ} \mathrm{C}$. The strains categorized as giving an equivocal test result were further investigated by incubation at $32^{\circ} \mathrm{C}$. Then, resistance was considered positive, when the inhibitory zone diameter decreased more than $4 \mathrm{~mm}$ at $32^{\circ} \mathrm{C}$ as compared with that at $35^{\circ} \mathrm{C}$.

3. DNA preparation

DNA preparation was based on Marmur's method ${ }^{6}$ with some modification. To a microtube was added $1.5 \mathrm{ml}$ of an overnight culture of $S$. aureus in brain heart infusion broth (Difco Laboratories, Detroit, MI) and the tube was centrifuged at 12,000 rpm for $5 \mathrm{~min}$. The precipitated cells were suspended in $400 \mu \mathrm{l}$ of saline-EDTA (0.1 M EDTA in $0.15 \mathrm{M} \mathrm{NaCl}, \mathrm{pH} 8.0)$, and $6 \mu 1$ of $1 \%$ (w/v) of sodium dodecyl sulfate and $4 \mu \mathrm{l}$ of $2 \%(\mathrm{w} / \mathrm{v})$ proteinase K (Wako Pure Chemical Industries Ltd., Osaka) in TE buffer (10 mM Tris- $\mathrm{HCl}, 1 \mathrm{mM}$ EDTA, pH 8.0) were added. Then the suspension was incubated at $37^{\circ} \mathrm{C}$ for $30 \mathrm{~min}$, and treated with $5 \mu 1$ of $1 \%$ (w/v) RNase (Nippon Gene, Co. Ltd., Tokyo) at $37^{\circ} \mathrm{C}$ for $30 \mathrm{~min}$. DNA was extracted with buffered phenol and then with chloroformisoamylalcohol $(24: 1)$, then precipitated with ethanol containing one-ninth volume of $3 \mathrm{M}$ sodium acetate. After centrifugation at $12,000 \mathrm{rpm}$, the precipitated DNA was washed with cold ethanol and dried in vacuo. DNA was resuspended in TE buffer for further experiments, and stored at $4^{\circ} \mathrm{C}$ until use.

4. Polymerase chain reaction analysis

Two oligonucleotide primers (sense, nucleotides 1282 to 1303 of mec $\mathrm{A}$ with the sequence 5'-AAAATCGATGGTAAAGGTTGGC-3', and antisense, nucleotides 1793 to 1814 of mec A with the sequence $5^{\prime}$-AGTTCTGCAGTACCGGATTTGC-3') ${ }^{1)}$, and other nucleotide primers (sense, nucleotides 766 to 789 of $f e m \mathrm{~A}$ with the sequence 5'-CGAGGTCATTGCAGCTTGCTTAC-3', and antisense, nucleotides 1736 to 1755 of $f e m \mathrm{~A}$ with the sequence $5^{\prime}$-CTAGACCAGCATCTTCAGC-3' $)^{2)}$ were synthesized and supplied by Nippon Gene.

PCRs were performed in a DNA thermal cycler by using a Gene Amp Kit according to the manufacturer's recommendations. The PCR conditions were $94^{\circ} \mathrm{C}, 30 \mathrm{sec}$ for denaturation; $60^{\circ} \mathrm{C}, 30 \mathrm{sec}$ for annealing; $72^{\circ} \mathrm{C}, 2$ min for primer extension; for 30 cycles in an MJ Research DNA thermal cycler. The PCR products were fractionated on $1 \%$ agarose gels.

5. Southern blot analysis

Extraction of the high molecular weight DNA and Southern blot analysis were performed according to the method described by Engler-Blum et al. ${ }^{7)}$ Filters prehybridized for $1 \mathrm{hr}$ at $68^{\circ} \mathrm{C}$ were hybridized with probes at $68^{\circ} \mathrm{C}$. The mec A and fem A probes were labelled by a DIG DNA Labeling 
Kit (Boehringer, Tokyo) and added to hybridization buffer. The fem A probe was a 990-bp fragment ${ }^{1)}$ from the PCR product of MRSA. The mecA probe was a 533-bp fragment ${ }^{2)}$ from the PCR product of MRSA. Filters were washed at $65^{\circ} \mathrm{C}$ in $0.1 \mathrm{M}$ maleic acid, $3 \mathrm{M} \mathrm{NaCl}, 0.3 \%$ Tween 20 and exposed to film with a DIG Luminescent Detection Kit (Boehring, Tokyo).

\section{Results}

1. Isolation of Staphylococcus spp.

Fifteen species of the genus Staphylococcus were isolated from the floor of the hospital ward in December 1992 and in April 1993, as shown in Table 1. In December 1992, 149 strains of Staphylococcus were isolated, of which only 2 strains were $S$. aureus. The isolation rate for S. epidermidis was the highest, and S. hominis, S. haemolyticus, S. warneri and S. capitis were main isolates. In contrast, there was a marked increase in the isolation rates for $S$. aureus and $S$. caprae in April 1993, and $S$. epidermidis, S. haemolyticus, S. hominis and S. warneri were also found (Table 1).

2. Antibiograms of the staphylococci

A total of 115 strains of the genus Staphylococcus were tested for susceptibility to 13 antibiotics (Table 2). MRSA was found to be resistant to many drugs. All 12 strains of MRSA were also resistant to ABPC and CLDM. The average number of resistance factors per strain was the highest in MRSA (7.9) and the next highest in S. haemolyticus (6.7). Eight of 10 strains of S. haemolyticus were resistant to methicillin. Only one strain of $S$. simulans was isolated throughout the experiment and it was resistant to 6 drugs.

Among the 13 drugs, ABPC resistance was observed in 47 of the 115 strains (40.9\%). Thirty-nine, 36 , and 43 of the 115 strains were resistant to DMPPC, MPIPC, and CZX, respectively. No strain resistant to MINO or VCM was isolated.

3. Detection of $f e m \mathrm{~A}$ and $m e c \mathrm{~A}$ genes

PCR amplification of a segment of the mec A gene or fem A gene from the staphylococci was performed (Fig. 1). The femA gene was observed in all the strains of S. aureus (MRSA and MSSA), but not in S. epidermidis, S. hominis or S. haemolyticus. The mecA gene was observed in all the 7

Table 1 Isolation of Staphylococcus in December 1992 and April 1993

\begin{tabular}{lccr}
\hline \multirow{2}{*}{ Species } & \multicolumn{2}{c}{ Stains isolated in : } & \\
\cline { 2 - 3 } & December & April & \\
\hline S. aureus & 2 & 27 & $29(10.6)$ \\
S. epidermidis & 73 & 25 & $98(35.8)$ \\
S. capitis & 10 & 5 & $15(5.5)$ \\
S. warneri & 12 & 12 & $24(8.8)$ \\
S. haemolyticus & 17 & 17 & $34(12.4)$ \\
S. hominis & 18 & 13 & $31(11.3)$ \\
S. auricularis & 4 & 4 & $8(2.9)$ \\
S. saprophyticus & 4 & 4 & $8(2.9)$ \\
S. cohnii & 4 & 3 & $7(2.6)$ \\
S. simulans & 1 & 0 & $1(0.4)$ \\
S. carnosus & 1 & 1 & $2(0.7)$ \\
S. sciuri & 1 & 0 & $1(0.4)$ \\
S. caprae & 2 & 12 & $14(5.1)$ \\
S. equorum & 0 & 1 & $1(0.4)$ \\
S. kloosi & 0 & 1 & $1(0.4)$ \\
\hline \multicolumn{1}{c}{ Total } & 149 & 125 & $274(100)$ \\
\hline
\end{tabular}


Table 2 Antibiotic susceptibility of the isolates to 13 antibiotics ${ }^{\text {a) }}$

\begin{tabular}{|c|c|c|c|c|c|c|c|c|c|c|c|c|c|c|c|c|}
\hline \multirow{2}{*}{ Species } & \multirow{2}{*}{ (No.) } & \multicolumn{13}{|c|}{ Number of strains resistant to: } & \multirow{2}{*}{ TRF } & \multirow{2}{*}{$(\text { ratio })^{b)}$} \\
\hline & & DMPPC & MPIPC & CZX & $\mathrm{ABPC}$ & CEZ & $\mathrm{CMZ}$ & IPM & GM & MINC & CLDM & LFLX & VCM & ST & & \\
\hline S. aureus (MSSA) & (17) & & & & 13 & & & & & & & & & & 13 & $(0.8)$ \\
\hline S. aureus (MRSA) & (12) & 12 & 12 & 12 & 12 & 11 & 9 & 5 & 8 & & 12 & 2 & & & 95 & (7.9) \\
\hline S. epidermidis & $(10)^{\text {c) }}$ & 2 & 1 & 3 & 4 & 1 & 1 & & & & 2 & & & & 14 & $(1.4)$ \\
\hline S. capitis & $(10)^{c)}$ & 1 & & 1 & 2 & & & & & & 1 & & & & 5 & $(0.5)$ \\
\hline S. warneri & $(10)^{c)}$ & 2 & 2 & 2 & 2 & & & & & & & & & & 8 & $(0.8)$ \\
\hline S. haemolyticus & $(10)^{\mathrm{c})}$ & 8 & 8 & 8 & 9 & 8 & 8 & 4 & 9 & & & 5 & & & 67 & $(6.7)$ \\
\hline S. hominis & $(10)^{c)}$ & 3 & 3 & 4 & & 2 & 3 & 1 & & & 1 & 1 & & & 18 & $(1.8)$ \\
\hline S. auricularis & $(8)$ & 4 & 4 & 4 & & 1 & 1 & & & & & 1 & & & 15 & $(1.9)$ \\
\hline S. saprophyticus & (8) & 4 & 4 & 4 & 4 & 4 & & & & & 2 & & & & 22 & $(2.8)$ \\
\hline S. cohnii & (7) & 2 & 2 & 4 & & 2 & & & & & 2 & & & & 12 & $(1.7)$ \\
\hline S. simulans & (1) & & & 1 & 1 & & & & 1 & & 1 & 1 & & 1 & 6 & $(6.0)$ \\
\hline S. carnosus & (2) & & & & & & & & & & & & & & 0 & $(0)$ \\
\hline S. sciuri & (1) & & & & & & & & & & & & & & 0 & $(0)$ \\
\hline S. caprae & (7) & 1 & & & & & & & & & & & & & 1 & $(0.3)$ \\
\hline S. equorum & (1) & & & & & & & & & & & & & & 0 & $(0)$ \\
\hline S. kloosi & (1) & & & & & & & & & & & & & & 0 & $(0)$ \\
\hline Total & (115) & 39 & 36 & 43 & 47 & 29 & 22 & 10 & 18 & 0 & 21 & 10 & 0 & 1 & 276 & (2.4) \\
\hline
\end{tabular}

${ }^{a}$ DMPPC, methicillin ; MPIPC, oxacillin ; CZX, ceftizoxime; ABPC, ampicillin ; CEZ, cefazolin ; CMZ, cefmetazole ; IPM, imipenem ; GM, gentamicin; MINO, minocycline; CLDM, clindamycin; LFLX, lomefloxacin; VCM, vancomycin; ST, sulfamethoxazole-trimetoprim ${ }^{b)}$ Total resistance factors (average number of resistance factors/strain)

${ }^{c}$ Ten strains each of these species were picked at random.

Fig. 1 PCR analysis of the mecA gene and the fem $\mathrm{A}$ gene from staphylococci

A 533-bp segment of the mecA gene (upper) and a 990-bp segment of the fem A gene (lower) were amplified from the lysate of $S$. aureus (A), and CNS (B). (A) M, size markers (in base pairs); lanes 1-7, MRSA; lanes 8-12, MSSA, (B) lanes 1-2, methicillin-resistant (MR) S. epidermidis; lanes 3-4, methicillin-sensitive (MS) S. epidermidis; lanes 5-6, MR-S. hominis; lanes 7-8, MS-S. hominis; lanes 9-10, MR-S. haemolyticus; lanes 11-12, MS-S. haemolyticus.

(A)

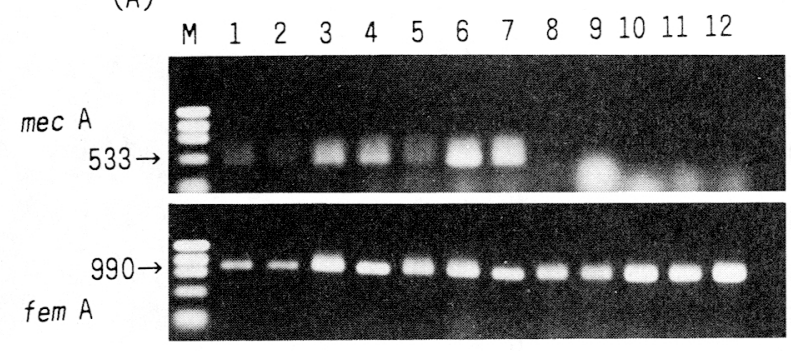

(B)

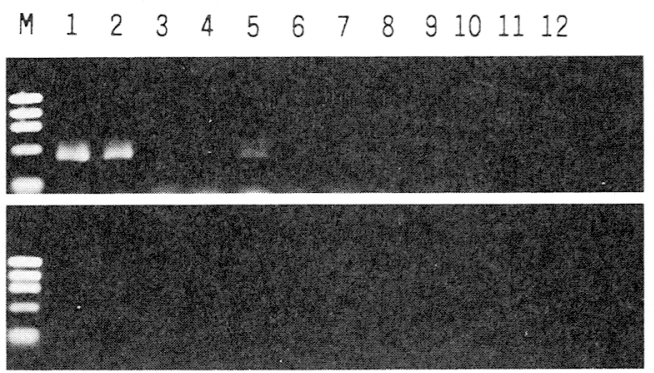

strains of MRSA tested, but not in 5 strains of MSSA. Two strains of methicillin-resistant (MR) S. epidermidis and one of 2 MR-S. hominis strains contained the mecA gene. No mecA gene was detected in the methicillin-sensitive strains of S. epidermidis, S. hominis or S. haemolyticus. Southern blot analysis using mec $\mathrm{A}$ and $f e m \mathrm{~A}$ probes showed that $f e m \mathrm{~A}$ and mec $\mathrm{A}$ genes were present in all the DNAs from the corresponding fem A- or mecA-positive strains (Fig. 2).

\section{Discussion}

We collected Staphylococcus from the new ward environment of Tottori University Hospital over 
Fig. 2 Southern blot analysis of Staphylococus spp.

The DNAs from S. aureus (A) and from CNS (B) were hybirdized with the mecA gene probe (upper) and the fem $\mathrm{A}$ gene probe (lower). The strain and the lane number are the same as shown in Fig. 1.

(A)

$\begin{array}{lllllllllllll}1 & 2 & 3 & 4 & 5 & 6 & 7 & 8 & 9 & 10 & 11 & 12\end{array}$
(B)

$\begin{array}{lllllllllllll}1 & 2 & 3 & 4 & 5 & 6 & 7 & 8 & 9 & 10 & 11 & 12\end{array}$
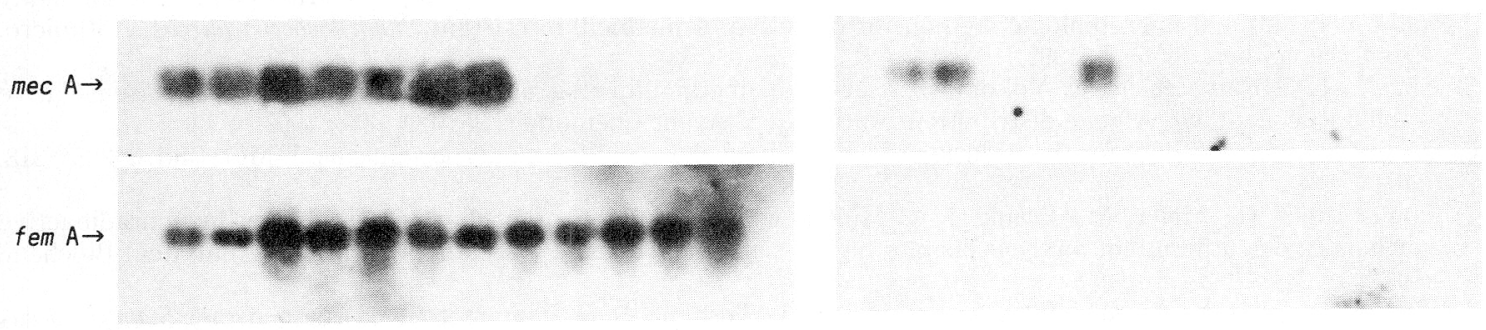

one year from 1991 to 1992, and tested their drug susceptibility ${ }^{8}$. The rates of isolation of S. aureus and of MRSA had gradually increased. The rates of isolation of S. aureus among Staphylocoecus spp. and of MRSA among S. aureus strains in January 1992 were 22 and 43\%, respectively. One year later, in this experiment, isolation rates for S. aureus and for MRSA among S. aureus were 10.6 and 41.4\%, respectively (Table 1). As it was widely recognized in Japan that 50 to $60 \%$ of S. aureus strains isolated from inpatients was MRSA, it may have been reasonable to find that 40 to $45 \%$ of $S$. aureus strains in the environment were methicillin resistant.

A PCR-based test was developed for the detection of the mecA gene, which encodes methicillin resistance in $S$. aureus ${ }^{1,3}$. This technique was extensively used for the rapid identification of MRSA. However, it was found that the DNA from staphylococci other than S. aureus also encodes mecA. Other DNA regions of the mecA genes were also selected as a primer by some investigators ${ }^{4,9,10)}$. Another gene, fem A, has been characterized as essential for the expression of $S$. aureus ${ }^{11)}$.

Yokoyama ${ }^{12)}$ used the DNA sequence encoding mec $\mathrm{A}$ and $f e m \mathrm{~A}$ genes as a double primer. We had used a double primer encoding mecA and fem A genes for identifying MRSA by a single PCR test. Unexpectedly, the strain which was positive in the PCR test with the primer for the mec A gene or fem A gene alone was negative in the PCR with the double primer. A strategy for selection of the double primer may be needed.

Throughout these experiments, some strains of methicillin-resistant Staphylococcus other than $S$. aureus (MR-CNS) were found not to contain mecA. This might be due to the diversity of DNA sequences of the gene which encodes the mec A product, or to an other celllular DNA which encodes methicillin resistance. Alternatively, two regulatory mec A genes were found ${ }^{13)}$; one is the mecI gene which suppresses the expression of the mec A gene, and the other is the mec R 1 gene which acts as an inducer of the mecA gene. Unusual expression of these regulatory genes for mec A might be responsible for methicillin resistance. Resolution of these discrepancies will require further studies.

At any rate, staphylococci isolated from a hospital ward were revealed to possess methicillin resistance at relatively high frequency, and a similar mec A gene was detected in S. aureus and also in CNS. If a compromised patient is contaminated with MR-staphylococci directly from the ward environment or from the medical staff, methicillin resistance is transferred to the patient's resident S. aureus, and an opportunistic and devilish infection might occur. Therefore, extreme care against MRSA and MR-CNS is necessary for clinical treatment of the compromised inpatients. 


\title{
References
}

1) Murakami, K., Minamide, W., Wada, K., Nakamura, E., Teraoka, H. \& Watanabe, S.: Identification of methicillinresistant strains of staphylococci by polymerase chain reaction. J. Clin. Microbiol. 29: 2240-2244, 1991.

2) Ünal, S., Hoskins, J., Flokowitsch, J.E., Wu, C.Y.E., Preston, D.A. \& Skatrud, P.L.: Detection of methicillinresistant staphylococci by using the polymarase chain reaction. J. Clin. Microbiol. 30: 1685-1691, 1992.

3) Hiramatsu, K., Kihara, H. \& Yokota, T.: Analysis of borderline-resistant strains of methicillin-resistant Staphylocuccus aureus using polymerase chain reaction. Microbiol. Immunol. 36: 445-453, 1992.

4) Tokue, Y., Shoji, S., Satoh, K., Watanabe, A. \& Motomiya, M.: Comparison of a polymerase chain reaction assay and a conventional microbiologic method for detection of methicillin-resistant Staphylococcus aureus. Antimicro. Agent Chemother. 36: 6-9, 1992.

5) Suzuki, E., Hiramatsu, K. \& Yokota, T.: Survey of methicillin-resistant clinical strains of coagulase-negative staphylococci for mecA gene distribution. Antimicrob. Agent Chemother. 36: 429-434, 1992.

6) Marmur, J.: A procedure for the isolation of deoxyribonucleic acid from microorganisms. J. Mol. Biol. 3: 208-218, 1961.

7) Engler-Blum, G., Meier, M., Frank, J. \& Müller, G.A.: Reduction of background problems in nonradioactive northern and southern blot analysis enables higher sensitivity than ${ }^{32} \mathrm{P}$-based hybridizations. Analytical Biochem. 210: 235-244, 1993

8) Tanaka, Y., Adachi, A., Ashimoto, A., Kishimoto, H., Teshima, R. \& Yamamoto, K.: Drug-resistant Staphylococcus aureus contamination in the ward environment. J. Japn. Assoc. Infect. Dis. 66: 1270-1275, 1992.

9) Brakstad, O.G., Aasbakk, K. \& Maeland, J.A.: Detection of Staphylococcus aureus by polymerase chain reaction amplification of the nuc gene. J. Clin. Microbiol. 30: 1654-1660, 1992.

10) Goh, S.-H., Byrne, S.K., Zhang, J.L. \& Chow, A.W.: Molecular typing of Staphylococcus aureus on the basis of coagulase gene polymorphisms. J. Clin. Microbiol. 30: 1642-1645, 1992.

11) Berger-Bächi, B., Berberis-Maino, L., Strässle, A. \& Kayser, F.: Fem A, a host-mediated factor essential for methicillin resistance in Staphylococcus aureus: molecular cloning and characterization. Mol. Gen. Genet. 219: $263-269,1989$.

12) Yokoyama, T.: Study on mec gene in methicillin-resistant staphylococci. J. Japn. Ass. Infect. Dis. 67: 1203-1210, 1994. (in Japanese with English abstract)

13) Hiramatsu, K., Asada, K., Suzuki, E., Okonogi, K. \& Yokota, T.: Molecular cloning and nucleotide sequence determination of the regulator region of mecA gene in methicillin-resistant Staphylococcus aureus (MRSA). FEBS Lett. 298: 133-136, 1992 .

\section{病棟におけるStaphylococcus 感染の分子疫学 \\ メチシリン耐性 Staphylococcus の mecA および fem A の研究}

\author{
鳥取大学医学部歯科口腔外科学教室 \\ 足本敦浜田驍 \\ 鳥取大学医学部細菌学教室
}

足立 昭子谷川 孝彦 田中 吉紀

\begin{abstract}
要旨
鳥取大学医学部附属病院病棟の床, 器具より Staphylococcus spp. の分離を試み, 合計 274 株の分 離株のうち29株がS. aureusで，S. aureus の 41.4\%がメチシリン耐性（MRSA）であった. 12 株の MRSA はまた MPIPC, CZX, ABPC, CLM にも耐性であった.CNS の中にもメチシリン耐性 (MR) の S. epidermidis, S. capitis, S. warneri, $S$. haemolyticus, S. hominis, $S$. auricularis, $S$. saprophyticus, S. cohnii などが分離された.

MRSA およびMSSA にみられたが, CNS には認 められなかった. mec A は MRSA と MR-S. epidermidis にみられ, MR-S. hominis の 2 株の うち 1 株に見られた. MSSA, MS-CNS には認め られなかった. MR-S. hominisの 1 株とS. haemolyticus の 2 株の DNAにはmecAが検出 できなかった。原因について考察を試みたが，い ずれにしても病棟環境中に MR-Staphylococcus が存在することを考えると, 院内感染に十分な注 意が必要である.
\end{abstract}

PCR およ゙ Southern blot分析でfemA は 